\title{
KEBERHARGAAN DIRI DAN RESILIENSI SEBAGAI PREDIKTOR SUCCESSFUL AGING PADA LANSIA DI PANTI WREDA
}

\author{
Dewi Agrianti Ralampi ${ }^{1}$ \& Christiana Hari Soetjiningsih \\ Universitas Kristen Satya Wacana, Jl. Diponegoro 52-60 Salatiga, 50711, Indonesia
}

Korespondensi:

Ie-mail: ralampiagri@gmail.com

\begin{abstract}
This study aimed to determine self-esteem and resilience as the predictors of successful aging among the elderly in nursing homes. This study used quantitative approach, participated by 127 elderly participants who live in nursing homes located in five cities in Central Java (Salatiga, Semarang, Surakarta, Magelang, and Pekalongan) (Mage = 74.57; SD = 7.49). This study utilized The Connor-Davidson Resilience Scale (to measure the level of resilience) and Rosenberg Self-esteem Scale (to measure the self-esteem) which were translated into Indonesian language. Successful Aging Scale were based on the Rowe and Kahn's theory (1987) of successful aging. The results indicated that there was a significant effect of selfesteem and resilience simultaneously $(F=10.975 ; p=.000)$ on successful aging, suggesting that self-esteem and resilience are predictors of successful aging. The results of this study could serve as a reference for the government and nursing home managements to improve successful aging of the elderly who live in nursing homes.
\end{abstract}

Article history:

Received 17 September 2018

Received in revised form 3 Desember 2018

Accepted 8 Februari 2019

Available online 14 April 2019

\section{Keywords:}

elderly;

resilience;

self-esteem;

successful aging

\begin{abstract}
Abstrak - Penelitian ini bertujuan untuk menentukan self-esteem (keberhargaan diri) dan resiliensi sebagai prediktor successful aging pada lansia di panti wreda. Penelitian ini menggunakan metode kuantitatif dengan jumlah partisipan sebanyak 127 lansia yang tinggal di panti wreda di lima kota di Jawa Tengah (Salatiga, Semarang, Surakarta, Magelang, dan Pekalongan) $\left(M_{\text {usia }}=74.57\right.$; SD $\left.=7.49\right)$. Penelitian ini menggunakan skala The Connor-Davidson Resillience Scale (untuk mengukur tingkat resiliensi) dan Rosenberg Self-esteem Scale (untuk mengukur keberhargaan diri) yang diterjemahkan ke dalam Bahasa Indonesia. Skala Successful Aging dibuat oleh penulis berdasarkan teori successful aging dari Rowe dan Kahn (1987). Hasil menunjukkan bahwa ada pengaruh signifikan dari keberhargaan diri dan resiliensi secara simultan $(F=10.975 ; p=.000)$ terhadap successful aging, mengindikasikan bahwa keberhargaan diri dan resiliensi merupakan prediktor successful aging. Hasil dari penelitian ini dapat menjadi salah satu acuan bagi pemerintah dan pengelola panti wreda untuk meningkatkan successful aging lansia yang tinggal di panti wreda.
\end{abstract}

Kata Kunci: lanjut usia; resiliensi; keberhargaan diri; successful aging 


\section{PENDAHULUAN}

Undang-Undang Republik Indonesia No. 13 Tahun 1998 menyatakan bahwa penduduk lanjut usia (lansia) adalah orang yang telah berusia 60 tahun ke atas. Hasil Survei Sosial Ekonomi Nasional yang dilakukan Badan Pusat Statistik (BPS) (2014) menunjukkan bahwa jumlah lansia di Indonesia mencapai 20.24 juta jiwa, setara dengan 8.03 persen dari seluruh penduduk Indonesia di tahun 2014. Himawan, Risnawaty, dan Wirawan (2014) bahkan memproyeksikan bahwa pada tahun 2050, jumlah individu berusia 60 tahun ke atas di Indonesia akan melebihi populasi individu yang berusia 0-14 tahun. Oleh karena itu, investigasi tentang kesejahteraan lansia merupakan hal yang penting untuk dilakukan. Berdasarkan data Kementerian Kesehatan Republik Indonesia (2017), jumlah lansia Indonesia pada tahun 2017 sebanyak 23.66 juta atau sekitar 9.03 persen dari jumlah penduduk Indonesia, kemudian diprediksi jumlah lansia pada tahun 2020 sebesar 27.08 juta, tahun 2025 sebanyak 33.69 juta, tahun 2030 sebanyak 40.95 juta, dan tahun 2035 sebanyak 48.19 juta. Dari data yang telah disebutkan, diketahui bahwa Indonesia masuk dalam kategori negara dengan struktur menuju tua (aging population), di mana jumlah lansia telah mencapai angka di atas tujuh persen.

Selain menunjukkan adanya peningkatan jumlah lansia setiap tahun, hal ini juga menunjukkan bahwa perlahan-lahan masyarakat Indonesia mulai sadar akan pentingnya hidup sehat. Kenaikan jumlah lansia menimbulkan permasalahan, yaitu kebutuhan akan pelayanan kesehatan yang ramah bagi lansia. Sementara itu, sarana dan prasarana pelayanan kesehatan bagi lansia sebagai upaya peningkatan kesehatan dan kesejahteraan lansia masih terbatas. Data Kementerian Kesehatan Republik Indonesia (2017) menunjukkan angka harapan hidup perempuan lebih tinggi daripada laki-laki. Hal ini terlihat dari keberadaan penduduk lansia perempuan yang lebih banyak daripada lansia laki-laki. Selain itu, angka beban ketergantungan mencerminkan beban ekonomi yang harus ditanggung oleh penduduk usia produktif untuk membiayai penduduk lansia dengan asumsi bahwa penduduk lansia tersebut secara ekonomi bukanlah lansia yang produktif. Data dari Kementerian Kesehatan pada tahun 2017 menunjukkan bahwa rasio ketergantungan penduduk lansia Indonesia pada tahun 2015 sebesar 13.28 persen, artinya setiap 100 orang penduduk usia produktif harus menanggung sekitar 14 orang penduduk lansia. Perkembangan rasio ketergantungan penduduk lansia dari tahun 2012 sampai dengan tahun 2015 tidak mengalami perubahan yang signifikan.

Program pemerintah untuk menyediakan pelayanan kesehatan dan meningkatkan kesejahteraan lansia saat ini masih belum terlaksana sepenuhnya. Hal ini dapat dilihat dari 
banyaknya lansia yang terlantar, lansia yang hidup di jalanan, lansia yang menjadi pemulung, lansia yang menjadi pengemis, serta lansia yang ditolak di panti sosial. Secara khusus, data BPS (2015) menunjukkan bahwa Jawa Tengah yang dikenal sebagai pusat budaya Jawa merupakan salah satu dari tiga propinsi dengan jumlah lansia terbanyak di Indonesia, setelah Jawa Timur dan Yogyakarta. Oleh karena itu, peneliti memutuskan memilih Jawa Tengah sebagai fokus penelitian.

Paradigma lama menyatakan bahwa lansia adalah sosok yang tidak berdaya dan hanya menjadi beban bagi keluarga, lingkungan, dan negara. Kini, paradigma yang harus dianut adalah lansia harus mencapai successful aging, yaitu tetap sehat, aktif, dan produktif (Soetjiningsih, 2018). Namun, beberapa faktor dapat memengaruhi pencapaian successful aging, salah satunya adalah status tinggal lansia. Pada kenyataannya, terdapat lansia yang tinggal sendiri, tinggal bersama keluarga atau anak, dan tinggal di panti wreda. Lansia yang tinggal di panti wreda membutuhkan perhatian, penanganan, dan perlakuan khusus yang berbeda dengan lansia yang tinggal sendiri di rumah atau tinggal bersama anak. Maka, studi mengenai successful aging di panti wreda menjadi penting untuk dilakukan.

Mencapai successful aging membutuhkan kesiapan untuk menerima segala perubahan dalam aspek-aspek kehidupan. Menurut Potter dan Perry (2005), terdapat tiga perubahan yang terjadi pada seorang lansia, yaitu perubahan fisiologis, perubahan perilaku psikososial, dan perubahan kognitif. Apabila perubahan sosial, fisik, dan kognitif yang dialami oleh lansia tidak dijalani dengan kesiapan dan penerimaan, maka hal ini bisa menjadi sumber stres.

Namun, tidak sedikit lansia yang mampu tetap optimal dalam bidang-bidang sosial dan mencapai kondisi sejahtera karena sebelum memasuki masa lansia sudah melakukan persiapan. Suardiman (2011) menyatakan bahwa keinginan untuk tetap mandiri, berguna, dihargai, dan tetap aktif berkarya merupakan harapan yang diinginkan oleh para lansia karena hal tersebut bertujuan agar terhindar dari perasaan kesepian, ketergantungan, dan tidak berdaya. Selain itu, Dyah dan Fournalistyawati (2018) menyatakan bahwa kemampuan lansia untuk memfokuskan pikiran pada masa kini juga dapat berpengaruh pada kesejahteraan psikologis lansia. Kondisi lansia yang terjaga kesehatannya, tetap aktif, dan mandiri akan menimbulkan rasa percaya diri, memupuk keberhargaan diri yang baik, dan membangkitkan perasaan puas sehingga para lansia dapat mencapai successful aging. 


\section{Successful Aging pada Lansia}

Secara umum, successful aging dipahami sebagai proses menjadi orang berusia tua yang baik (atau berhasil) atau sesuatu yang baik dan diharapkan (Schulz \& Heckhausen, 1996). Menurut Rowe dan Kahn (1987), individu yang mencapai successful aging adalah individu yang memiliki kemampuan mengelola tiga karakteristik atau perilaku. Pertama, yaitu meminimalisasi risiko munculnya berbagai penyakit dan akibat yang berhubungan dengan penyakit tersebut sehingga memiliki kemungkinan yang kecil untuk terjangkit suatu penyakit. Hal ini merupakan aspek yang sangat penting dalam mencapai successful aging. Karakteristik yang kedua yaitu mengelola secara baik fungsi-fungsi fisik maupun psikis karena keberfungsian kognitif pada lansia berkaitan dengan proses belajar dan ingatan. Untuk menjaga dan menstabilkan keberfungsian kognitif pada lansia, terdapat empat prediktor yang harus diperhatikan, yaitu pendidikan, kesehatan paru-paru dan pernapasan, aktivitas fisik rutin, dan efikasi diri lansia. Karakteristik yang ketiga yaitu keterlibatan aktif dengan kehidupan, di mana ada keaktifan berkaitan dengan keanggotaan dan kegiatan sosial atau organisasi masyarakat setelah usia 60 tahun. Kemudian, Crowther, Parker, Achenbaum, Larimore, dan Koenig (2002) menambahkan satu karakteristik, yaitu aspek spiritualitas yang positif (positive spirituality) yang melibatkan hubungan pribadi yang berkembang dan tidak terikat oleh ras, etnis, ekonomi, atau kelas serta mempromosikan kesehatan dan kesejahteraan, baik diri sendiri maupun orang lain. Spiritualitas yang positif merupakan penggabungan dari konsep agama dan spiritual. Keempat faktor tersebut saling berhubungan dan memengaruhi satu sama lain.

Baltes dan Baltes (1990) menjelaskan bahwa successful aging merupakan perpaduan antara fungsi-fungsi biologis (kesehatan dan daya tahan tubuh), fungsi-fungsi psikologis (kesehatan mental), dan aspek-aspek positif seseorang sebagai manusia (kompetensi sosial, kontrol diri, dan kepuasan hidup). Konsep successful aging dari Baltes dan Baltes tersebut dikenal dengan model SOC, yaitu Selection, Optimization, dan Compensation. Model ini berasumsi bahwa setiap individu selalu berada di dalam proses adaptasi secara kognitif yang terjadi di sepanjang hidupnya dan kehidupan seseorang akan selalu mengalami perubahan dalam makna dan tujuan hidup.

Successful aging adalah hal yang bersifat subjektif. Hal ini akan terjadi ketika seseorang mencapai tujuan yang diinginkan dengan bermartabat dan mandiri, serta menggunakan waktu sebanyak mungkin untuk melakukan hal-hal yang bermakna. Successful aging juga dilihat sebagai kepuasan internal dari penyesuaian terhadap kondisi eksternal (Suardiman, 2011). Oleh karena successful aging merupakan kondisi yang relatif subjektif bagi seseorang, maka kondisi ini dapat dirasakan oleh seseorang dengan cara dan kadar yang berbeda-beda. Fungsi sosial yang 
berkelanjutan adalah salah satu tujuan successful aging yang meliputi kemampuan tinggi dalam memfungsikan peran sosial, interaksi antar sesama, serta partisipasi dalam masyarakat. Menjalani masa tua dengan bahagia dan sejahtera merupakan keinginan semua orang, sehingga setiap lansia diharapkan mampu menghadapi setiap perubahan-berubahan yang dialaminya untuk mencapai kesejahteraan dan kebahagiaan di hari tuanya, baik secara fisik, psikis, dan sosialnya.

\section{Successful Aging pada Lansia di Panti Wreda}

Utari, Hartati, dan Duryati (2014) menunjukkan bahwa tingkat successful aging lansia yang tinggal di panti wreda berada pada kategori tinggi. Hal ini disebabkan oleh kegiatan-kegiatan di dalam panti yang telah dibuat oleh pengelola panti untuk para lansia. Penelitian lain yang dilakukan oleh Khotimah (2016) juga menunjukkan bahwa successful aging pada lansia di panti wreda berada pada kategori tinggi karena dipengaruhi oleh pengertian successful aging pada masing-masing partisipan.

Pada penelitian ini, sebelum melakukan penelitian, penulis melakukan observasi pada 20 orang lansia yang tinggal di panti wreda dengan tujuan melihat gambaran kehidupan sehari-hari lansia yang tinggal di panti wreda, keadaan fisik dan kognitif para lansia, kegiatan-kegiatan yang dilakukan, cara para lansia berinteraksi satu sama lain, serta cara berinteraksi para lansia dengan pegawai panti wreda. Observasi ini dilakukan tiga kali pada awal bulan Juni 2018. Dari hasil observasi, dapat disimpulkan sementara bahwa lansia yang tinggal di panti wreda belum sepenuhnya mencapai successful aging. Hal ini dikarenakan kebanyakan lansia yang tinggal di panti wreda sudah tidak memiliki fungsi kognitif yang baik, mulai pikun dan sering mengulang pembicaraan, serta tidak sedikit yang memiliki fisik yang sudah lemah sehingga hal ini memengaruhi fungsi fisik.

Mengingat successful aging merupakan salah satu tujuan dari perkembangan tahap akhir pada lansia, successful aging bukanlah suatu kondisi yang terbentuk begitu saja, melainkan kondisi yang sengaja diciptakan dan dibentuk oleh seseorang sesuai dengan yang diperlukan. Oleh sebab itu, keberadaan successful aging ditentukan oleh berbagai faktor yang ikut memberikan kontribusi, serta menentukan mampu tidaknya seseorang memperoleh atau mencapai successful aging.

Hunter, Linn, dan Harris (1982) menunjukan bahwa semakin tua seseorang, maka keberhargaan diri yang dimiliki menjadi semakin rendah karena mereka memandang diri tidak lagi berguna dan berharga, sehingga hal ini memengaruhi successful aging mereka. Sama halnya dengan hasil penelitian Candra, Rahayu, dan Sumarwati (2016) yang menunjukkan bahwa terdapat 
hubungan positif yang sangat kuat dan signifikan antara keberhargaan diri dengan pencapaian successful aging pada lansia. Selain itu, Jeste dkk. (2013) menunjukkan bahwa resiliensi berhubungan secara signifikan dengan successful aging pada lansia.

\section{Keberhargaan Diri sebagai Prediktor Successful Aging pada Lansia}

Hyun, Ju, dan Sok (2012) mengemukakan bahwa keberhargaan diri merupakan salah satu faktor yang memengaruhi successful aging pada lansia. Keberhargaan diri juga disebut sebagai keberhargaan diri atau gambaran diri. Keberhargaan diri adalah sikap yang dimiliki tentang dirinya sendiri, baik positif maupun negatif (Rosenberg, 1965). Rosenberg menyatakan bahwa keberhargaan diri memiliki dua aspek, yaitu penerimaan diri dan penghormatan diri. Kedua aspek tersebut memiliki lima dimensi, yaitu dimensi akademik, sosial, emosional, keluarga, dan fisik. Dimensi akademik mengacu pada persepsi individu terhadap kualitas pendidikan individu. Dimensi sosial mengacu pada persepsi individu terhadap hubungan sosial individu. Dimensi emosional merupakan hubungan keterlibatan individu terhadap emosi individu. Dimensi keluarga berfokus pada keterlibatan individu dalam partisipasi dan integrasi di dalam keluarga. Sedangkan, dimensi fisik mengacu pada persepsi individu terhadap kondisi fisik individu.

Dalam penelitian ini, penulis menggunakan aspek-aspek yang dikemukakan oleh Rosenberg (1965), yaitu penerimaan diri dan penghormatan diri, di mana kedua aspek tersebut memiliki lima dimensi, antara lain dimensi akademik, sosial, emosional, keluarga, dan fisik.

\section{Resiliensi sebagai Prediktor Successful Aging pada Lansia}

Selain keberhargaan diri, MacLeod, Hawkins, Musich, Wricker, dan Alsgaard (2016) menyatakan bahwa salah satu faktor yang memengaruhi successful aging adalah resiliensi. Resiliensi mencerminkan sebuah keyakinan bahwa individu dapat melakukan sebuah respons di bawah kondisi stres secara efektif (Kobasa, Maddi, \& Kahn, 1982). Resiliensi diperkenalkan pertama kali oleh Block (dalam Klohnen, 1996) dengan nama ego-resillience, yaitu kemampuan umum yang melibatkan penyesuaian diri yang tinggi dan tidak kaku saat dihadapkan pada tekanan internal maupun eksternal.

Resiliensi menurut Connor dan Davidson (2003) terdiri dari lima aspek yaitu: 1). kompetensi personal, standar yang tinggi, dan keuletan, 2). kepercayaan naluriah seseorang untuk bertoleransi dan bereaksi positif terhadap hal-hal negatif, 3). penerimaan positif terhadap perubahan serta kemampuan membangun hubungan yang baik dengan orang lain, 4). kontrol diri untuk 
mencapai tujuan dan meminta atau mendapatkan bantuan dari orang lain, dan 5). adanya keyakinan spiritual.

\section{Rumusan Masalah}

Berdasarkan uraian yang telah dipaparkan di atas, maka perumusan masalah dalam penelitian ini adalah apakah keberhargaan diri dan resiliensi secara simultan merupakan prediktor successful aging pada lansia yang tinggal di panti wreda di Jawa Tengah. Hipotesis penelitian ini adalah keberhargaan diri dan resiliensi secara simultan merupakan prediktor successful aging pada lansia yang tinggal di panti wreda di Jawa Tengah.

\section{METODE}

\section{Partisipan}

Partisipan berjumlah 127 orang (27.6\% laki-laki; $72.4 \%$ perempuan; $M_{\text {usia }}=74.57 ; S D=$ 7.49) yang tinggal di panti wreda di Jawa Tengah, meliputi kota Salatiga, Semarang, Surakarta, Magelang, dan Pekalongan. Kriteria partisipan dalam penelitian ini adalah berusia 60 tahun ke atas, komunikatif (masih dapat diajak komunikasi, masih paham dengan apa yang ditanyakan, dan masih dapat menjawab pertanyaan yang diajukan saat wawancara), dan bersedia untuk menjadi partisipan.

\section{Instrumen}

The Connor-Davidson Resillience Scale. Alat ukur resiliensi awalnya dikembangkan oleh Connor dan Davidson (2003) sebagai suatu pengukuran ringkas untuk membantu mengukur resiliensi dan pengukuran di klinik agar dapat melihat respons dari suatu intervensi. Butir-butir resiliensi menggambarkan tentang kontrol, yaitu perasaan atau tanggapan seseorang tentang makna dan tujuan hidup dengan kepedulian terhadap diri sendiri dan orang lain. Komitmen adalah perasaan atau tanggapan seseorang mengenai otonomi dan kemampuan untuk memengaruhi jalan hidup atau pola hidup sendiri. Tantangan adalah perasaan atau tanggapan seseorang di mana ia memaknai tantangan sebagai bagian alami dari kehidupan yang menyediakan kesempatan untuk bertumbuh dan perubahan yang dipandang sebagai tantangan juga dimasukkan. Skala ini terdiri dari lima aspek yaitu: 1). kompetensi personal, standar yang tinggi, dan keuletan, 2). kepercayaan naluriah seseorang untuk bertoleransi dan bereaksi positif terhadap hal-hal negatif, 3). penerimaan positif terhadap perubahan, serta kemampuan membangun hubungan yang baik dengan orang lain, 
4). kontrol diri untuk mencapai tujuan dan meminta atau mendapatkan bantuan dari orang lain, dan 5). adanya keyakinan spiritual, serta memiliki 15 pernyataan dengan contoh-contoh pernyataan dalam skala sebagai berikut: 'saya belajar dari pengalaman masa lalu', 'saya berusaha melakukan yang terbaik tentunya agar mencapai hasil akhir yang terbaik pula.' Nilai yang didapat dari hasil uji reliabilitas dan daya diskriminasi butir adalah 10 butir yang memiliki rentang nilai yang bergerak dari .532 sampai .872 dengan nilai Alpha Cronbach ialah .918 yang berarti alat ukur ini layak dipakai.

Skala Successful Aging. Skala ini disusun oleh penulis berdasarkan teori Rowe dan Kahn (1987) dengan menggunakan tiga karakteristik. Pertama, yaitu meminimalisasi risiko munculnya berbagai penyakit dan akibat yang berhubungan dengan penyakit tersebut, sehingga memiliki kemungkinan kecil untuk terjangkit suatu penyakit, sebab hal ini merupakan aspek yang sangat penting dalam mencapai successful aging. Karakteristik yang kedua, yaitu mengelola secara baik fungsi-fungsi fisik maupun psikis karena keberfungsian kognitif pada lansia berkaitan dengan proses belajar dan ingatan. Karakteristik yang ketiga, yaitu keterlibatan aktif dengan kehidupan, di mana terdapat keaktifan berkaitan dengan keanggotaan dan kegiatan sosial atau organisasi masyarakat setelah usia 60 tahun. Sama seperti skala resiliensi, skala successful aging juga memiliki 15 pernyataan. Berikut merupakan contoh-contoh pernyataan dalam skala ini, yaitu 'saya belajar dari pengalaman masa lalu', 'saya berusaha melakukan yang terbaik tentunya agar mencapai hasil akhir yang terbaik pula.' Sesudah melakukan uji reliabilitas dan daya diskriminasi butir, diperoleh 10 butir dengan rentang nilai .365 sampai .855 dan koefisien Alpha Cronbach ialah .875 yang berarti alat ukur ini layak dipakai.

Rosenberg Self-Esteem Scale. Skala ini dikembangkan oleh Rosenberg (1965) dan memiliki dua aspek, yaitu penerimaan diri dan penghormatan diri. Kedua aspek tersebut memiliki lima dimensi, yaitu dimensi akademik, sosial, emosional, keluarga, dan fisik. Dimensi akademik mengacu pada persepsi individu terhadap kualitas pendidikan individu. Dimensi sosial mengacu pada persepsi individu terhadap hubungan sosial individu. Dimensi emosional merupakan hubungan keterlibatan individu terhadap emosi individu. Dimensi keluarga berfokus pada keterlibatan individu dalam partisipasi dan integrasi di dalam keluarga. Sedangkan, dimensi fisik mengacu pada persepsi individu terhadap kondisi fisik individu. Skala ini terdiri dari 10 pernyataan dengan contoh-contoh pernyataan sebagai berikut: 'saya memiliki sejumlah kualitas yang baik', 'saya memiliki sikap positif terhadap diri sendiri.' Sesudah uji reliabilitas dan daya diskriminasi butir, didapati bahwa 10 butir tersebut memiliki daya diskriminasi yang baik dengan rentang nilai .373 
sampai .758 dan koefisien Alpha Cronbach sebesar .854 yang berarti alat ukur ini layak dipakai untuk penelitian karena memiliki daya diskriminasi yang baik. Ketiga skala di atas memiliki empat pilihan jawaban (rating scales) yang harus dipilih oleh partisipan, yaitu SS (Sangat Sesuai), S (Sesuai), TS (Tidak Sesuai), dan STS (Sangat Tidak Sesuai).

\section{Prosedur}

Teknik sampling dalam pengambilan partisipan, yaitu purposive dan quota sampling, di mana pengambilan sampel sesuai dengan kriteria yang sudah ditetapkan oleh penulis dan jumlah sampel menggunakan kuota yang sudah ditentukan sesuai perencanan. Oleh karena penelitian ini menggunakan metode kuantitatif, maka pelaksanaan pengambilan data menggunakan metode pengisian skala secara mandiri. Namun, terdapat pula beberapa partisipan yang dibantu dan didampingi dalam pengisian skala oleh penulis atau pegawai panti atau kerabat dalam mengisi skala tersebut.

\section{Teknik Analisis}

Teknik analisis data yang digunakan dalam penelitian ini adalah analisis regresi berganda, yaitu untuk menguji keberhargaan diri dan resiliensi secara simultan sebagai prediktor successful aging. Perhitungan regresi berganda dengan menggunakan software SPSS 20.0. Namun, sebelum dilakukan analisis data, terlebih dahulu dilakukan uji asumsi, yaitu normalitas, multikolinieritas, heterokedastisitas, dan liniearitas.

Uji normalitas dengan menggunakan data residual diperoleh nilai $K S Z=.640(p=.808)$, berarti data berdistribusi normal. Hasil juga menunjukkan tidak adanya efek multikolinearitas antar variabel $(.1<V I F<10)$. Observasi terhadap grafik untuk uji heterokedastisitas menunjukkan titiktitik menyebar dan tidak membentuk pola yang jelas sehingga dapat disimpulkan bahwa tidak terjadi heterokedasitas. Uji linearitas menunjukkan nilai $F=11.081(p=.0001)$, sehingga dapat disimpulkan bahwa successful aging dan keberhargaan diri memiliki hubungan linier. Hasil uji linearitas antara successful aging dan resiliensi menunjukkan nilai $F=14.601(p=.0001)$, sehingga dapat disimpulkan bahwa successful aging dan resiliensi memiliki hubungan linier. 


\section{ANALISIS DAN HASIL}

Pertama dilakukan uji signifikan simultan untuk menguji pengaruh keberhargaan diri dan resiliensi secara simultan terhadap variabel successful aging. Hasil menunjukkan adanya kontribusi signifikan dari keberhargaan diri dan resiliensi $(F=10.975 ; R=.388 ; p=.000)$ terhadap successful aging partisipan. Jadi, hipotesis penelitian diterima.

Dari hasil perhitungan koefisien determinasi diperoleh hasil .150 yang menunjukkan bahwa keberhargaan diri dan resiliensi memberikan sumbangan sebesar 15 persen pada successful aging, sedangkan sisanya sebesar 85 persen dipengaruhi oleh variabel lain yang tidak diteliti dalam penelitian ini.

Lebih lanjut, dari hasil perhitungan diketahui bahwa keberhargaan diri $(\beta=.238 ; t=2.819$; $p=.006)$ dan resiliensi $(\beta=.264 ; t=3.137 ; p=.002)$ secara parsial berkontribusi signifikan terhadap successful aging.

Untuk mengetahui seberapa besar pengaruh antara keberhargaan diri dan resiliensi terhadap successful aging dilakukan perhitungan sumbangan efektif terhadap variabel $\mathrm{x}$ dengan menggunakan rumus $\mathrm{SE}(\chi) \%=\beta \chi$ x Koefisien Korelasi x $100 \%$. Hasil perhitungan menunjukkan bahwa sumbangan efektif keberhargaan diri terhadap successful aging sebesar 7 persen dan sumbangan efektif resiliensi terhadap successful aging sebesar 8 sebesar.

\section{DISKUSI}

Hasil analisis menunjukkan bahwa secara simultan terdapat pengaruh antara keberhargaan diri dan resiliensi terhadap successful aging pada lansia yang tinggal di panti wreda di Jawa Tengah. Keberhargaan diri dan resiliensi secara simultan menjadi prediktor successful aging.

Selain itu, berdasarkan hasil pengujian dapat dilihat bahwa keberhargaan diri dan resiliensi juga berpengaruh terhadap successful aging secara parsial. Adanya pengaruh antara keberhargaan diri dan resiliensi terhadap successful aging dapat dijelaskan dengan kondisi lokasi penelitian, karakteristik subjek, serta nilai-nilai budaya dan keagamaan yang dianut. Penelitian ini dilakukan di Jawa Tengah. Partisipan penelitian ini merupakan orang-orang dengan suku Jawa, sehingga nilainilai yang dianut oleh subjek bisa memengaruhi hasil dari penelitian ini. Salah satu hal yang mungkin memengaruhi tingginya tingkat resiliensi dan keberhargaan diri adalah nilai-nilai 
keagamaan yang mengajarkan untuk tetap bertahan di bawah kesesakan, sehingga hal ini memengaruhi tingginya tingkat successful aging. Hal ini terbukti pada saat wawancara tambahan dengan beberapa subjek bahwa mereka merupakan orang yang aktif dalam komunitas dan kegiatan keagamaan serta memegang nilai-nilai keagamaan dalam kehidupan. Hal ini mendukung penelitian Nindialoka (2017) yang menyatakan bahwa salah satu faktor yang memengaruhi pencapaian successful aging pada lansia adalah nilai-nilai agama yang dianut oleh lansia tersebut. Selain itu, nilai-nilai kehidupan yang dianut oleh para subjek yang merupakan mayoritas masyarakat Jawa adalah nrimo (atau narimo) ing pandum. Maharani (2018) mendefinisikan nrimo ing pandum sebagai sikap menerima dengan utuh terhadap apa yang diberikan oleh kehidupan. Falsafah nrimo ing pandum mengandung tiga konstruk psikologis, yaitu penerimaan, kesabaran, dan kebersyukuran. Nilai hidup itu yang digunakan sebagai pegangan dalam menjalani ujian kehidupan, sehingga hal ini memengaruhi para subjek dalam menghadapi permasalahan yang dapat memengaruhi keberhargaan diri dan resiliensi yang berujung pada tingginya tingkat successful aging. Hal ini dapat diartikan bahwa apabila seseorang memiliki penerimaan dan penghormatan diri yang tinggi, maka ia akan memiliki successful aging yang tinggi.

Hasil penelitian ini juga memperkuat penelitian Adrianisah dan Septiningsih (2013) yang menyatakan bahwa resiliensi dalam menghadapi berbagai tantangan dalam kehidupan subjek dapat membantu mereka mencapai kesuksesan di masa tuanya. Hal ini mendukung penelitian Candra, Rahayu, dan Sumarwati (2016) yang menunjukkan bahwa terdapat hubungan positif yang sangat kuat dan signifikan secara statistik antara keberhargaan diri dengan pencapaian successful aging. Selain itu, penelitian yang dilakukan Jeste dkk. (2013) yang menunjukkan bahwa resiliensi memiliki hubungan yang signifikan dengan successful aging.

Pada penelitian ini juga diperoleh sumbangan efektif yang digunakan untuk mengetahui seberapa besar sumbangan efektif dari masing-masing variabel, yaitu keberhargaan diri sebesar tujuh persen dan resiliensi sebesar delapan persen. Hal ini menunjukkan bahwa dari 100 persen prediktor yang memengaruhi successful aging, 15 persen berasal dari keberhargaan diri dan resiliensi, sedangkan sisanya berasal dari prediktor yang tidak diteliti dalam penelitian ini. Kemudian, hal ini juga menunjukkan bahwa terdapat pengaruh yang signifikan dari keberhargaan diri dan resiliensi terhadap successful aging. Berdasarkan beberapa penelitian terdahulu, successful aging dipengaruhi oleh banyak prediktor, seperti dukungan sosial, optimisme, spiritualitas, dan lainlain. Faktor-faktor tersebut juga memengaruhi tingkat pengaruh keberhargaan diri dan resiliensi terhadap successful aging. Hal ini sejalan dengan penelitian yang dilakukan oleh Hyun dkk. (2012) 
yang menyatakan bahwa keberhargaan diri berpengaruh terhadap successful aging seseorang, juga dengan penelitian Jeste dkk. (2013) yang mengatakan bahwa resiliensi memiliki hubungan dengan successful aging.

Berdasarkan hasil penelitian, keberhargaan diri dan resiliensi yang tinggi berpengaruh terhadap tingkat successful aging yang tinggi pada lansia. Hal ini dikarenakan individu yang memiliki keberhargaan diri tinggi akan memiliki persepsi yang baik terhadap pendidikan dan hubungan sosial, serta memiliki kondisi emosional dan kondisi fisik yang lebih baik (Coopersmith, 1967). Rutter (dalam Connor \& Davidson, 2003) mengemukakan bahwa individu dengan tingkat resiliensi yang tinggi memiliki ciri-ciri sebagai berikut: Memiliki strategi pengembangan dengan arah yang jelas atau realistis dalam menentukan pilihan, adanya suatu orientasi dalam tindakan, adanya suatu keyakinan kuat atau efikasi diri, kemampuan beradaptasi ketika berhadapan dengan perubahan, memiliki keterampilan dalam memecahkan masalah sosial, humor dalam menghadapi stres, ketegaran dalam menghadapi stres, perasaan yang stabil, dan pengalaman keberhasilan di masa lalu. Dengan demikian, lansia yang memiliki keberhargaan diri dan resiliensi yang tinggi akan terpacu atau terdorong untuk mewujudkan perilaku-perilaku sesuai dengan karakteristik successful aging yang tinggi, yaitu meminimalisasi munculnya berbagai penyakit dan akibatnya, serta memiliki kemungkinan kecil untuk terjangkit suatu penyakit. Selain itu, lansia akan terdorong untuk mengelola dengan baik fungsi fisik maupun psikis karena fungsi kognitif pada lansia berkaitan erat dengan proses belajar dan daya ingat. Untuk menjaga kestabilan fungsi kognitif tersebut, maka hal yang harus diperhatikan adalah pendidikan, kesehatan paru-paru serta pernafasan, aktivitas fisik, dan efikasi diri para lansia. Lansia juga akan berusaha untuk memiliki keterlibatan aktif dengan kehidupan, yaitu keaktifan yang berkaitan dengan keanggotaan, kegiatan komunitas keagamaan, dan kegiatan sosial di lingkungannya.

\section{SIMPULAN DAN SARAN}

\section{Simpulan}

Berdasarkan hasil penelitian, terdapat pengaruh yang signifikan keberhargaan diri dan resiliensi secara simultan terhadap successful aging. Oleh karena itu, dapat disimpulkan bahwa keberhargaan diri dan resiliensi secara simultan menjadi prediktor successful aging pada lansia di panti wreda. 


\section{Saran Teoretis}

Penelitian selanjutnya dapat mempertimbangkan faktor-faktor lain, terutama yang berkaitan dengan kearifan lokal masyarakat sebagai prediktor successful aging. Hasil penelitian ini dapat menjadi rujukan dalam merancang dan menguji efektivitas intervensi untuk meningkatkan successful aging para lansia yang tinggal di panti wreda.

\section{Saran Praktis}

Hasil penelitian ini dapat bermanfaat bagi pemegang kebijakan dalam menyusun program dan kebijakan sosial untuk menyejahterakan lansia yang tinggal di panti wreda. Bagi pengurus panti wreda, diharapkan mereka dapat mempersiapkan kegiatan-kegiatan yang dapat meningkatkan atau mempertahankan keberhargaan diri dan resiliensi para lansia.

\section{UCAPAN TERIMA KASIH}

Ucapan terima kasih penulis haturkan kepada para pengurus serta responden di beberapa panti wreda di Jawa Tengah (yang meliputi Semarang, Salatiga, Surakarta, Magelang, dan Pekalongan). Penulis juga menghaturkan terima kasih kepada Dinas Penanaman Modal dan Pelayanan Terpadu Satu Pintu (DPMPTSP), Dinas Kesatuan Bangsa dan Politik (Kesbangpol) Jawa Tengah, serta Kesbangpol masing-masing kota dengan dikeluarkannya surat izin penelitian.

\section{SPONSOR}

Penelitian ini merupakan penelitian Hibah Pascasarjana yang didanai oleh Kemenristek Dikti Republik Indonesia.

\section{REFERENSI}

Adrianisah, M. N., \& Septiningsih, D. S. (2013). Penelitian tentang successful aging (studi tentang lanjut usia yang anak dan keluarganya tinggal bersama). Psycho Idea, 11(1), 1693-1076.

Badan Pusat Statistik. (2014). Statistik penduduk lanjut usia 2014. Indonesia: Badan Pusat Statistik. Badan Pusat Statistik. (2015). Statistik penduduk lanjut usia 2015. Indonesia: Badan Pusat Statistik. 
Baltes, P. B., \& Baltes, M. M. (1990). Psychological perspective on successful aging: The model of selective optimization with compensation. New York, NY: Cambridge University Press.

Candra, R. A. A., Rahayu, E., \& Sumarwati, M. (2016). Hubungan antara harga diri dengan pencapaian successful aging pada lansia wanita di Desa Karangtengah. Jurnal Kesmas Indonesia, 8(2), 15-30.

Connor, K. M., \& Davidson, J. R. T. (2003). Development of a new resilience scale: The connordavidson resilience scale (CD-RISC). Depression and Anxiety, 18(2), 76-82. doi: 10.1002/da.10113

Coopersmith, S. (1967). The antecedents of self-esteem. San Francisco, CA: W. H. Freeman.

Crowther, M. R., Parker, M. W., Achenbaum, W. A., Larimore, W. L., \& Koenig, H. G. (2002). Rowe and Kahn's model of successful aging revisited: Positive spirituality- The forgotten factor. The Gerontologist, 42(5), 613-620.

Dyah, A. S. P., \& Fourianalistyawati, E. (2018). Peran trait mindfulness terhadap kesejahteraan psikologis pada lansia. Jurnal Psikologi Ulayat, 5(1), 109-122. doi: 10.24854/jpu12018-115

Himawan, K. K., Risnawaty, W., \& Wirawan, H. (2014). Effect of reminiscence group therapy on depressive symptoms of the nursing home elderly residents in Tangerang, Indonesia: A pilot study. The Guidance Journal, 42, 1-19.

Hunter, K. I., Linn, M. W., \& Harris, R. (1982). Characteristics of high and low self-esteem in the elderly. The International Journal of Aging and Human Development, 14(2), 117-126. doi: 10.2190/bgvm-2x68-ppfq-eyv8

Hyun, C. N., Ju, S. E., \& Sok, S. R. (2012). Factors influencing the successful aging of older Korean adults. Contemporary Nurse, 41(1), 78-87. doi: 10.5172/conu.2012.41.1.78

Jeste, D. V., Savla, G. N., Thompson, W. K., Vahia, I. V., Glorioso, D. K., Martin, A. S., .. \& Depp, C. A. (2013). Association between older age and more successful aging: Critical role of resilience and depression. American Journal of Psychiatry, 170(2), 188-196. doi: 10.1176/appi.ajp.2012.12030386

Kementerian Kesehatan Republik Indonesia. (2017). Analisis lansia di Indonesia. Jakarta: Kementerian Kesehatan Republik Indonesia.

Khotimah, Y. K. (2016). Successful aging pada lanjut usia (studi kasus pada balai pelayanan sosial lanjut usia dewanata Desa Slarang Kecamatan Kesugihan Kabupaten Cilacap) (Skripsi tidak dipublikasikan). Institut Agama Islam Negeri Purwokerto, Indonesia. 
Klohnen, E. C. (1996). Conceptual analysis and measurement of the construct of ego-resiliency. Journal of Personality and Social Psychology, 70(5), 1067-1079. doi: 10.1037/00223514.70.5.1067

Kobasa, S. C., Maddi, S. R., \& Kahn, S. (1982). Hardiness and health: A prospective study. Journal of Personality and Social Psychology, 42(1), 168-177. doi: 10.1037/0022-3514.42.1.168

MacLeod, S., Musich, S., Hawkins, K., Alsgaard, K., \& Wicker, E. R. (2016). The impact of resilience among older adults. Geriatric Nursing, 37(4), 266-272. doi: 10.1016/j.gerinurse.2016.02.014

Maharani, R. (2018). Penerapan falsafah narimo ing pandum dalam pendekatan person-centered untuk mengatasi depresi remaja. Prosiding SNBK (Seminar Nasional Bimbingan dan Konseling), 2(1), $205-212$.

Nindialoka, H. (2017). Dinamika psikologis proses pencapaian successful aging pada lansia pensiunan (Skripsi tidak dipublikasikan). Universitas Islam Negeri Maulana Malik Ibrahim Malang, Indonesia.

Potter, P. A., \& Perry, A. G. (2005). Buku ajar fundamental keperawatan: Konsep, proses, dan praktik (Edisi 4 Volume 1). Jakarta: Penerbit Buku Kedokteran EGC.

Rosenberg, M. (1965). Society and the adolescent self-image. Princeton, NJ: Princeton University Press.

Rowe, J. W., \& Kahn, R. L. (1987). Human aging: Usual and successful. Science, 237(4811), 143149. doi: $10.1126 /$ science. 3299702

Schulz, R., \& Heckhausen, J. (1996). A life span model of successful aging. American Psychologist, 51(7), 702-714. doi: 10.1037/0003-066x.51.7.702

Soetjiningsih, C. H., Samiyono, D., Ralampi, D.A., Simatauw, S.V., Amaheka, B.G.A., \& Amaral, F.M. (2018). Potret lansia successful aging. Jakarta: Prenadamedia Group.

Suardiman, S. P. (2011). Psikologi usia lanjut. Yogyakarta: Gadjah Mada University Press.

Undang-Undang Republik Indonesia. (1998). Undang-undang Republik Indonesia nomor 13 tahun 1998 tentang kesejahteraan lanjut usia. Ditemu kembali dari http://www.bpkp.go.id/uu/filedownload/2/45/438.bpkp

Utari, A.W., Hartati, N., \& Duryati. (2014). Perbedaan successful aging pada lansia di panti werdha ditinjau dari jenis kelamin (Skripsi tidak dipublikasikan). Fakultas Ilmu Pendidikan Universitas Negeri Padang, Indonesia. 